\section{A state-and-transition approach to alpine grasslands under abandonment}

\begin{abstract}
Targetti S ${ }^{(1)}$, Staglianò N ${ }^{(1)}$, Messeri A ${ }^{(2)}$, Argenti G ${ }^{(1)}$
The abandonment of the traditional pastoral practices is acknowledged as the main causes of the shrub-encroachment in the alpine semi-natural grasslands. In this paper, we proposed a state-and-transition approach in order to organize pastoral vegetation in a simple management-oriented framework integrating ecological data. The study sites were chosen in an inner alpine territory where the abandonment of pastoral practices was more evident than in other alpine regions. Cluster and fuzzy analysis applied to botanical data allowed the classification of six pastoral types and the assessment of the main overlaps between them. Non-parametric tests on Landolt nutrients indices, slope and distance from farm allowed the identification of a gradient linked with nutrients and pastoral practices intensity from rich pastures to shrub encroached pastures. Moreover, the implementation of the available information in a state-andtransition model (STM) allowed us to hypothesize the presence of an ecological threshold between grass-dominated and shrub-dominated grasslands and the identification of the at-risk pastoral types in the shrub-encroachment dynamics.
\end{abstract}

Keywords: Pastoral types, State-and-transition model, Shrub encroachment, Landolt ecological indices, Grazing management

\section{Introduction}

Alpine semi-natural grasslands represent both a traditional landscape element and the basis of the local pastoral systems. These complex agro-ecosystems are a distinctive example of interaction between man and natural resources which is based on long-established farming systems and related agricultural practices.

The alpine pastoral system is based traditionally on the "vertical transhumance" (i.e., livestock movement from lowlands to upland pastures for the summer season). During the 20th century alpine grasslands were involved in a general diminution of their productive importance due to social and economic forces such as the depopulation of mountain areas, marginalisation of local agriculture and the development of more remunerative activities (MacDonald et al. 2000), con-

(1) Department of Plant, Soil and Environmental Science, P.le delle Cascine 18, I-50144 Firenze (Italy); (2) CIRSEMAF, P.le delle Cascine 18, I-50144 Firenze (Italy)

(a), Stefano Targetti

(stefano.targetti@unifi.it)

Received: Sep 03, 2009 - Accepted: Jan 08, 2010

Citation: Targetti S, Staglianò N, Messeri A, Argenti G, 2010. A state-and-transition approach to alpine grasslands under abandonment. iForest 3: 44-51 [online: 2010-03-02] URL: http://www.sisef.it/ iforest/doi.php?doi=10.3832/ifor0525-003 sequently, the abandonment of agricultural practices caused widespread changes in traditional land management which was directly related to shrub encroachment in grasslands (Jewell et al. 2005), long term decrease of species and landscape biodiversity (Nösberger \& Rodriguez 1996, Wallis De Vries et al. 2007), hydrologic disorders and wild-fires (Romero-Calcerrada \& Perry 2004) and with irreversible loss of traditional customs (Sabatini et al. 2003).

This situation has led policy-makers to design ad hoc policies for marginal areas to preserve mountain farming (e.g., European Agricultural Policy, Dir. 2001/41/EU, Reg. 2003/1782/EU and 2005/1698/EU) to promote mountain pasture conservation and extensive grazing (Barthram et al. 2002). As a matter of fact, it appears that grazing and conservation of traditional practices are an appropriate way to preserve upland pastures and slow down shrub encroachment on a long term basis (Pollock et al. 2007).

In human-managed ecosystems it is common to find empirical evidence of ecological discontinuities and the existence of states has been recognised since 1960 s, these concepts belong to the non-linear ecological model (Muradian 2001). Several studies suggest that shrub encroachment leads the ecosystem to an "alternate stable state", defined by a specific ecological threshold, the main characteristic of alternate state systems is that transition needs intensive practices in order to revert the succession (Beisner et al. 2003). Such behaviour can also be highlighted in alpine grasslands where the grazing reduction triggers an ecosystem shift from grassland communities to shrub-invaded pastures. Once the equilibrium is broken, the increasing of the stocking rate will not return the community to its initial conditions, thus an ecological threshold has been passed and significant resources input like roller chopping, fire and seeding together with grazing management are necessary to revert the transition.

State-and-transition model (STM) is a framework in which it is possible to apply non-linear ecology and alternate stable states concepts. The general aim is to reorganize knowledge about grasslands in order to facilitate research and practical management. Many efforts have been made to build STMs for arid and semi-arid grasslands (Westoby et al. 1989, Jackson \& Bartolome 2002) and the US Natural Resources Conservation Service and other federal agencies adopted them in rangeland evaluation (Briske et al. 2005). Except for a few examples (Quétier et al. 2007) STMs for alpine grasslands have not yet been developed.

In the present work we propose a STM approach for upland pastures in an inner alpine territory characterised by widespread shrub encroachment on grasslands and by a generalised diminution of pastoral activities. The development of the STM followed Bestelmeyer et al. (2003) recommendations:

- identification of the range of plant communities in the area under study;

- definition of the extent over which a single STM will apply, based upon values of soil and climate variables (land units or ecological sites);

- definition of the pathways between the plant communities occurring within each ecological site;

- definition of states and transitions based upon available information (botanical notions, empirical observations, environmental conditions).

\section{Material and methods}

The study was carried out on more than 3300 ha of semi-natural grasslands located in four contiguous valleys in the eastern Italian Alps (Veneto Region), namely the Sesìs, Visdende, Digòn and High Pàdola valleys. The pastures under study are located along the national border between Italy and Austria: the mean annual temperature is $2.7{ }^{\circ} \mathrm{C}$ and the mean annual precipitation is 1288 $\mathrm{mm}$ at $1941 \mathrm{~m}$ above sea level, $55 \%$ of annual rainfall occurs during the growing season (climate data from Campobon pluviometric station, at a latitude of $46^{\circ} 38^{\prime} \mathrm{N}$ and longitude of $12^{\circ} 36^{\prime} \mathrm{E}$, approximately located in the middle of the area being studied - Fig. 1). The substrate is heterogeneous: main parent 
Fig. 1 - Localization of the area under study.

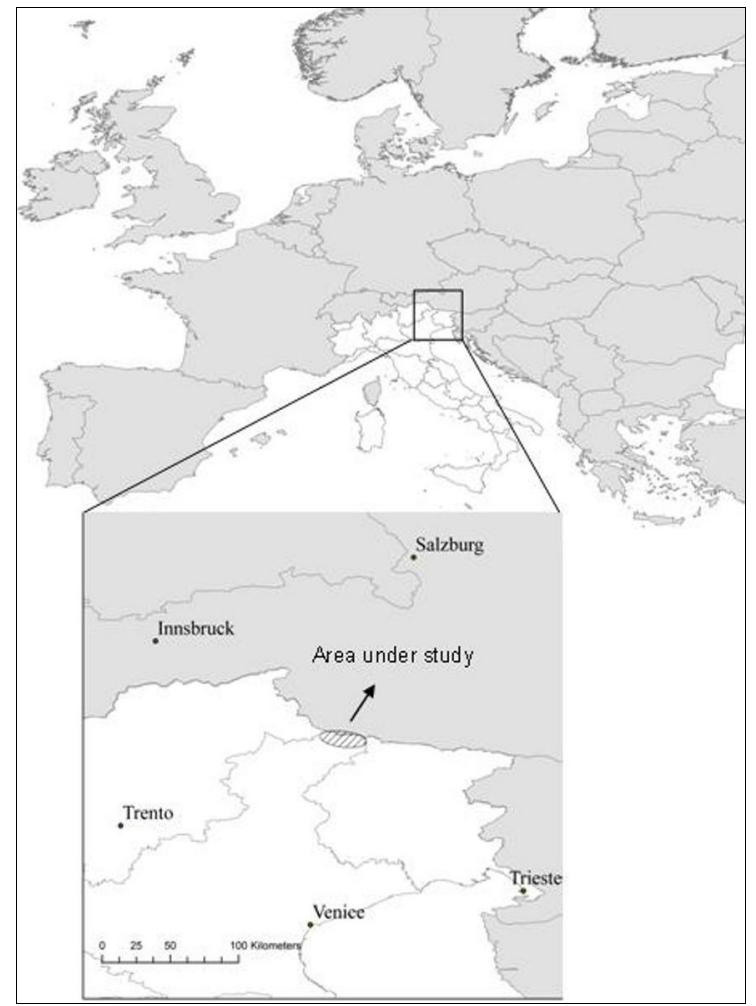

materials are shale-clay (siliceous) and calcareous-dolomite.

The farming system is extensive. Current key features of the mountain pastures management can be summarized as follows:

- absence of inorganic manure;

- cattle manure represented the main input, such as by the spreading of dairy slurry, and is limited to the pastures neighbouring the farms;

- absence of specific agriculture practices such as mowing or burning-off;

- absence of specific infrastructures like paddocks for cattle distribution on grasslands.

Semi-natural pastures are traditionally grazed during the summer season from June to September, but the area under study is characterized by a remarkable reduction in the number of dairy farms and related activities: from 1970 to 2000 livestock head decreased by $70 \%$, meadow and pasture hectares decreased by $50 \%$ (Italian National Institute of Statistics data). Therefore negative effects related to the abandonment of pastoral practices, like shrub encroachment in mountain pastures, are more evident than in other alpine regions.

\section{Identification of pastoral types}

Mountain pastures were localized with the aid of aerial photographs and local landmanagement documents, botanical relevés (transects) were positioned in order to represent a pastoral unit defined as a homogeneous area from the point of view of vegetation, management and ecology. The transects were recorded on a GPS device and the homogeneous areas were marked on regional maps (1:10000 technical maps - Veneto Region Cartographic Service).

Botanical field survey of mountain pastures was based on 386 point quadrat transects following the Daget and Poissonet method (Daget $\&$ Poissonet 1969): the transects were 6.6 $\mathrm{m}$ long, 33 intercepts (one intercept every 20 $\mathrm{cm}$ ) were materialized on the ground with a metal stick, the species touching the stick were identified and the number of times a species was found in the transect was counted. Species nomenclature followed Pignatti (1982). Species frequency (SF) was then converted into specific contribution (SC) in the following way (eqn. 1):

$$
S C_{i}=\frac{S F_{i}}{\sum_{i}^{n} S F} \cdot 100
$$

where $S C_{\mathrm{i}}$ is the specific contribution of the $i$ species and $S F_{\mathrm{i}}$ is the frequency of the $i$ species.

Hierarchical agglomerative clustering (Bray-Curtis distance, Ward agglomeration method) was applied to the matrix relevés $x$ SC. The goal of the cluster analysis was the identification of the plant communities of the area under study. We chose to employ the vegetation typology able to join both scientific and management purposes (Bassignana \& Bornard 2004). Pastoral types are vegetation groups resulting from environmental conditions and pastoral practices, homogeneous from the point of view of ecological pastoral types classification because it is a exigencies and botanical composition, which are identified by the dominance of 1-3 species (Cavallero et al. 2005). Interpretation of cluster analysis results (dendrogram) was based on botanical concepts: each pastoral type was characterized by two or three dominant species and a rather homogeneous species composition.

In absence of historical data, we employed the Landolt's $\mathrm{N}$ index to highlight the relationships between grazing management and pastoral types. $\mathrm{N}$ index is one of the eight ecological indices proposed by Landolt (1977) originally for the characterization of the Swiss flora, but they were usefully applied in other alpine environments (e.g., Lonati 2005). The $\mathrm{N}$ index evaluates the nutrient availability (mainly nitrogen) in a site through the botanical composition, whereas $\mathrm{F}$ index evaluates moisture. A value on a scale of 1 to 5 is given to a species catalogue (the high values indicating plants occurring mainly at nutrient- and moisture-rich sites), consequently nutrient availability was assessed for each transect through the weighted averages of the $\mathrm{N}$ index values. The link between the $\mathrm{N}$ index and grazing was based on the characteristics of the extensive pastoral system in the area under study where nutrient input on the grasslands consisted almost exclusively of cattle manure, therefore concentration of nutrients was strongly influenced by grazing intensity and differences in stocking rate levels.

All the information gathered and the map of the pastoral types were georeferenced and plotted on GIS support.

\section{Definition of ecological sites}

The STM approach requires the identification of land units defined by relatively homogeneous ecological conditions (ecological sites) in order to distinguish managementproduced from natural patterns in the plant communities' dynamics.

Ecological sites were defined considering geological substrate and elevation, as these proved to be the main environmental factors affecting grassland vegetation in the area examined (Sabatini et al. 2001): we considered two substrate types (siliceous vs. calcareous) and two elevation types, defined by timberline. Theoretical timberline (about $2200 \mathrm{~m}$ above sea level in the studied Alp district) was chosen as a threshold between two different ecological sites because it defines two different potential vegetation structures. Calcareous and siliceous sites were defined by employing existing geological maps (Braga et al. 1971). The area of each pastoral type was calculated and assigned to the ecological sites by GIS tools: the results were analysed by chi-square test in order to highlight, using statistical evidence, the existing links between ecological sites and pastoral types. Expected areas for 
chi-square test were weighted as follows (Ferrari \& D'Antuono 1981 - eqn. 2):

$$
E_{x j}=t_{x} \cdot s_{j} / S
$$

where $E_{\mathrm{xj}}$ is the expected area for type $x$ in the site $j, t_{\mathrm{x}}$ is the sum of the areas for type $x$, $S_{\mathrm{j}}$ is the sum of the areas for ecological site $j$ and $S$ is the general sum of the areas (3320 ha).

\section{Definition of pathways, states and transitions between pastoral types}

With the aim to assess the dynamics and the relationships between pastoral types, a fuzzy clustering was applied to the matrix reléves $x$ SC. Fuzzy clustering is a multivariate statistical technique that defines the degree of membership of observations to a set of clusters: the output is a new matrix in which the membership of each relevés is expressed as a percentage (Kaufman \& Rousseeuw 1990). In the absence of long term data-sets, pathways in the STM have been defined on the basis of the overlaps between pastoral types pointed out by fuzzy analysis.

In order to evaluate the differences among the pastoral types in each ecological site, Kolmogorov-Smirnov post-hoc test for unbalanced data was applied to N, F index values resulting from botanical transects to evaluate statistical differences between the pastoral types in each ecological site. Slope and distance from the nearest farm for each transect were also analysed by non-parametric test because they are typically in relationship with grazing intensity in alpine pastoral systems (Bornard \& Dubost 1992). Statistical analysis was carried out using $\mathrm{R}$ statistical software (R Development Core Team 2006) and Systat 9.

Available information about studied grasslands was organized into one STM for each ecological site, botanical survey and stati- stical analysis were the basis of the models, nonetheless other sources of information such as local farmers' information, expert knowledge, empirical observations and botanical references were considered. Pathways between pastoral types were identified and characterized by fuzzy analysis and nonparametric test. Ecological thresholds, defined as "boundaries between different states which define the passing of an irreversible transition and the changing of the primary ecological processes" (Stringham et al. 2003), were identified when reversion of vegetation shifts needed intensive practices such as seeding, fire, shrubs elimination, etc.

\section{Results}

\section{Identification of pastoral types}

The 386 field transects distributed on 3320 ha of semi-natural grasslands (on average 9 ha per transect) represented the basis of the present work. Some 319 vascular species were identified in the survey; to reduce redundancy which typically affects botanical data (Kent \& Coker 1992), we agreed to discard species below the SC threshold of 5\% in each transect, thereby the classification matrix consisted of 386 reléves $x 163$ species.

Transect ordination through hierarchical cluster analysis and the interpretation of the related dendrogram allowed the identification of six pastoral types (Fig. 2).

The classification pointed out a rather homogeneous botanical composition (Tab. 1). The six pastoral types were defined by clear differences in species composition as each type was defined by different dominant species: Carex curvula in type 1, Vaccinium myrtillus and Calluna vulgaris in type 4, Sesleria varia and Carex sempervirens in type 5, Deschampsia caespitosa, Alchemilla gr. vulgaris and Festuca gr. rubra in type 6;
Types 2 and 3, on the contrary, were characterized by the same two main species: Festuca gr. rubra and Nardus stricta $(12.0 \%$ Festuca gr. rubra and $8.0 \%$ Nardus stricta in type 2, 11.6\% Nardus stricta and 9.6\% Festuca gr. rubra in type 3, respectively).

Species belonging to Poaceae were dominant in the studied grasslands (Tab. 2). Furthermore, this was the most represented botanic family in all the pastoral types except in type 4; in particular types 2,3 and 6 were characterized by the highest presence of Poaceae (43, 42 and 45 percent respectively), whereas types 1 and 4 were characterized by the lowest presence $(29 \%)$. Pastoral type 4 was also characterized by the highest presence of Ericaceae (37\%) which were mainly represented by Vaccinium spp., Calluna vulgaris (dwarf-shrub species) and Rhododendron ferrugineum (shrub species). Kruskal-Wallis post-hoc test pointed out significant differences across the dominant botanic families among the six pastoral types.

SC attributed to plant life-forms sensu Raunkiaer (1934) highlighted a clear dominance of hemicryptophytes (Tab. 3). The lowest value was attributed to type 4 (59\%), whereas the highest value was attributed to type $6(98 \%)$. Chamaephytes presence was remarkable in types 4 and $5(27 \%$ and $13 \%$ respectively), whereas it was generally low in the other types (e.g., 0\% in type 6). Chamaephytes in type 4 comprised typical encroaching species such as Vaccinium myrtillus, Calluna vulgaris, and Vaccinium vitisidaea: chamaephytes in type 5 were mainly Thymus gr. serpyllum, Helianthemum nummularium, Erica carnea, Rhododendron hirsutum and Dryas octopetala which are typical species on stony calcareous soils. Type 4 was also characterized by the highest values relating to nanophanerophytes $(11 \%$, represented by Rhododendron ferrugineum and

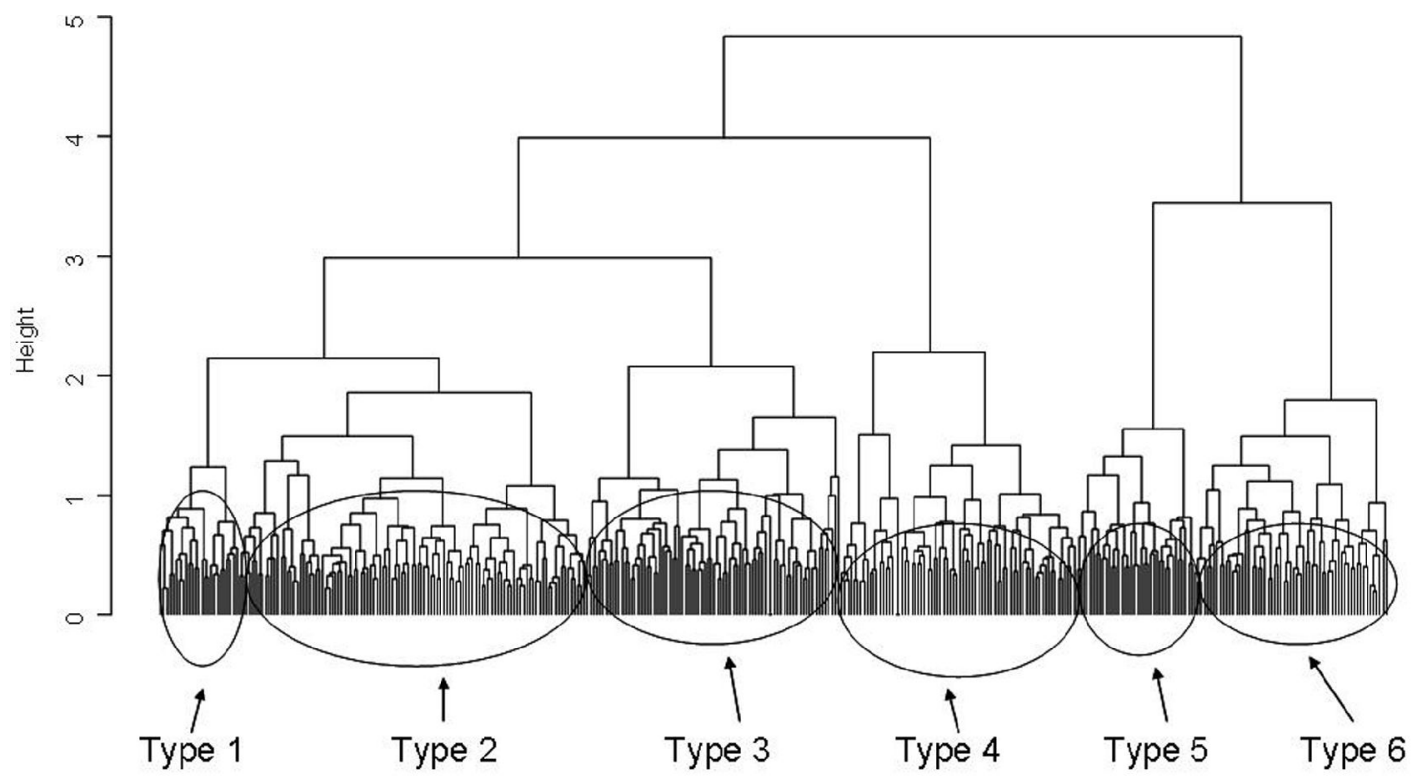

Fig. 2 - Cluster dendrogram. The transects comprising the six pastoral types are highlighted by circles. 
Tab. 1 - Dominant species and specific contribution (SC) in each pastoral type.

\begin{tabular}{|c|c|c|c|c|c|}
\hline \multicolumn{2}{|l|}{ Type 1} & \multicolumn{2}{|l|}{ Type 2} & \multicolumn{2}{|l|}{ Type 3} \\
\hline species & SC & species & SC & species & SC \\
\hline Carex curvula & 15.9 & Festuca gr. rubra & 12.0 & Nardus stricta & 11.6 \\
\hline Leontodon helveticus & 7.2 & Nardus stricta & 8.0 & Festuca gr. rubra & 9.6 \\
\hline Pulsatilla alpina & 6.8 & Phleum alpinum & 5.6 & Potentilla aurea & 6.9 \\
\hline Festuca gr. rubra & 6.5 & Potentilla aurea & 4.7 & $\begin{array}{l}\text { Anthoxanthum odorat- } \\
\text { um }\end{array}$ & 6.5 \\
\hline Primula minima & 6.2 & $\begin{array}{l}\text { Anthoxanthum } \\
\text { odoratum }\end{array}$ & 3.8 & Leontodon helveticus & 6.1 \\
\hline $\begin{array}{l}\text { Anthoxanthum odorat- } \\
\text { um }\end{array}$ & 5.1 & Potentilla erecta & 3.8 & Geum montanum & 6.0 \\
\hline Avenula versicolor & 4.7 & Ranunculus montanus & 3.4 & Homogyne alpina & 5.0 \\
\hline Potentilla aurea & 4.7 & Leontodon helveticus & 2.6 & Poa alpina & 3.7 \\
\hline Nardus stricta & 4.4 & Leontodon hispidus & 2.4 & Phleum alpinum & 3.2 \\
\hline Leontodon hispidus & 3.7 & Trifolium repens & 2.4 & Leontodon hispidus & 3.2 \\
\hline Type 4 & & Type 5 & & Type 6 & \\
\hline species & SC & species & $\mathrm{SC}$ & species & SC \\
\hline Vaccinium myrtillus & 9.6 & Sesleria varia & 10.4 & $\begin{array}{l}\text { Deschampsia } \\
\text { caespitosa }\end{array}$ & 10.4 \\
\hline Calluna vulgaris & 8.8 & Carex sempervirens & 9.1 & Alchemilla gr. vulgaris & 10.4 \\
\hline Nardus stricta & 8.2 & Festuca gr. rubra & 8.5 & Festuca gr. rubra & 10.0 \\
\hline Vaccinium vitis idaea & 6.2 & Lotus alpinus & 4.2 & Phleum alpinum & 9.4 \\
\hline $\begin{array}{l}\text { Rhododendron ferru- } \\
\text { gineum }\end{array}$ & 6.0 & Polygonum viviparum & 4.1 & Ranunculus montanus & 7.0 \\
\hline Festuca gr. rubra & 5.8 & Avenula versicolor & 3.4 & Trifolium repens & 4.8 \\
\hline Juniperus nana & 4.7 & Ranunculus montanus & 3.0 & Agrostis tenuis & 3.1 \\
\hline Avenella flexuosa & 2.9 & Anthyllis vulneraria & 3.0 & Trifolium pratense & 2.8 \\
\hline Vaccinium uliginosum & 2.9 & Homogyne alpina & 2.7 & Achillea gr. millefolium & 2.6 \\
\hline Carex sempervirens & 2.9 & Thymus gr. serpyllum & 2.5 & Trifolium thalii & 2.2 \\
\hline
\end{tabular}

Tab. 2 - Mean specific contribution (\%) of the main botanic family in each pastoral type. Kruskal-Wallis post hoc test $(* * *): \mathrm{P}<0.001$.

\begin{tabular}{lccccccc}
\hline \multicolumn{1}{c}{ Family } & Type 1 & Type 2 & Type 3 & Type 4 & Type 5 & Type 6 & p \\
\hline Compositae & 18.5 & 18.6 & 14.5 & 10.3 & 11.0 & 9.2 & $* * *$ \\
Cyperaceae & 16.8 & 4.9 & 4.8 & 4.7 & 10.2 & 2.0 & $* * *$ \\
Ericaceae & 5.3 & 4.0 & 2.3 & 37.1 & 4.9 & 0 & $* * *$ \\
Juncaceae & 1.6 & 0.7 & 0.9 & 2.7 & 0.3 & 0 & $* * *$ \\
Labiatae & 0.7 & 0.3 & 2.0 & 0.4 & 6.5 & 1.3 & $* * *$ \\
Leguminosae & 0 & 6.0 & 7.9 & 0.7 & 11.9 & 10.9 & $* * *$ \\
Poaceae & 29.3 & 43.1 & 42.3 & 28.6 & 31.2 & 44.8 & $* * *$ \\
Ranuncolaceae & 6.9 & 2.6 & 4.6 & 2.2 & 3.9 & 8.7 & $* * *$ \\
Rosaceae & 7.4 & 15.9 & 12.2 & 7.4 & 3.6 & 13.6 & $* * *$ \\
Umbelliferae & 0 & 2.3 & 1.2 & 0 & 0 & 2.2 & $* * *$ \\
\hline
\end{tabular}

Juniperus nana) and phanerophytes (1\%, mainly Larix decidua). On aggregate, nanophanerophytes, phanerophytes and chamaephytes reached $39 \%$ of SC in pastoral type 4 . This evidence highlighted an important invasion of shrub-species and the presence, although only $1 \%$, of tree-species, which likely pointed towards an early phase of forest re-growth process. Kruskal-Wallis test pointed out significant differences concerning life forms (except for terophytes) between the six pastoral types.

\section{Definition of ecological sites} calcareous areas indicated a clear dominance of siliceous substrate in the studied grasslands (296 ha for calcareous substrate vs. 3025 ha for siliceous substrate - Tab. 4), chisquare test linked types 1,3 and 4 to siliceous substrates and type 5 to calcareous substrate $(\mathrm{p}<0.01)$, types 2 and 6 were distributed on both substrates and they did not show any links to a specific substrate. Therefore two ecological sites linked with sub-
The differentiation between siliceous and strate typology were identified

- siliceous sites (pastoral types 1, 2, 3, 4 and 6);

- calcareous sites (pastoral types 2, 5 and 6). A second chi-square test was subsequently applied in siliceous and calcareous sites, to two elevation levels (above and below timberline - Tab. 5). The analysis did not show specific links in calcareous areas; on the contrary, high significance resulted in siliceous areas: type 1 was linked with high altitude pastures $(\mathrm{p}<0.01)$, types 4 and 6 were linked with areas below timberline $(\mathrm{p}<0.01$ and $p<0.05$ respectively), whereas types 2 and 3 highlighted no specific links.

As a result three ecological sites were defined:

- siliceous sites above $2200 \mathrm{~m}$ linked with types 1, 2 and 3 (site A);

- siliceous sites below $2200 \mathrm{~m}$ linked with types 2, 3, 4, 6 (site B);

- calcareous sites linked with types 2, 5 and 6 (site C).

Only three types (1, 4 and 5) were assigned to a single ecological site, types 2 , and 6 were linked with two different ecological sites, pastoral type 3 was linked with all the ecological sites identified in the studied area.

Tab. 3 - Mean specific contribution (\%) of Raunkiaer's life forms in each pastoral type. h: hemycryptophytes; ch: chamaephytes; g: geophytes; np: nanophanerophytes; t: terophytes; p: phanerophytes. Kruskal-Wallis post hoc test; (***): $\mathrm{p}<0.001 ; \quad$ (ns): $\mathrm{p}>0.05$.

\begin{tabular}{cccccccc}
\hline \multirow{2}{*}{$\begin{array}{c}\text { Life } \\
\text { Forms }\end{array}$} & \multicolumn{8}{c}{ Type } & & p \\
\cline { 2 - 7 } & $\mathbf{1}$ & $\mathbf{2}$ & $\mathbf{3}$ & $\mathbf{4}$ & $\mathbf{5}$ & $\mathbf{6}$ & \\
\hline $\mathrm{h}$ & $91^{\mathrm{b}}$ & $90^{\mathrm{ab}}$ & $92^{\mathrm{ab}}$ & $59^{\mathrm{d}}$ & $80^{\mathrm{c}}$ & $98^{\mathrm{a}}$ & $* * *$ \\
$\mathrm{ch}$ & $6^{\mathrm{c}}$ & $6^{\mathrm{c}}$ & $5^{\mathrm{c}}$ & $27^{\mathrm{a}}$ & $13^{\mathrm{b}}$ & $0^{\mathrm{d}}$ & $* * *$ \\
$\mathrm{~g}$ & $1^{\mathrm{c}}$ & $3^{\mathrm{b}}$ & $1^{\mathrm{c}}$ & $1^{\mathrm{c}}$ & $5^{\mathrm{a}}$ & $2^{\mathrm{bc}}$ & $* * *$ \\
$\mathrm{np}$ & $1^{\mathrm{b}}$ & $1^{\mathrm{bc}}$ & $1^{\mathrm{bc}}$ & $11^{\mathrm{a}}$ & $1^{\mathrm{bc}}$ & $0^{\mathrm{c}}$ & $* * *$ \\
$\mathrm{t}$ & $1^{\mathrm{a}}$ & $0^{\mathrm{a}}$ & $1^{\mathrm{a}}$ & $1^{\mathrm{a}}$ & $1^{\mathrm{a}}$ & $0^{\mathrm{a}}$ & $\mathrm{ns}$ \\
$\mathrm{p}$ & $0^{\mathrm{ab}}$ & $0^{\mathrm{ab}}$ & $0^{\mathrm{ab}}$ & $1^{\mathrm{a}}$ & $0^{\mathrm{ab}}$ & $0^{\mathrm{b}}$ & $* * *$ \\
\hline
\end{tabular}

Tab. 4 - Pastoral type areas in siliceous and calcareous sites. Chi-square test on weighted values; $(* *)$ : $\mathrm{P}<0.01$; (ns): not significant at $\mathrm{P}<0.05$.

\begin{tabular}{lccc}
\hline $\begin{array}{c}\text { Pastoral } \\
\text { type }\end{array}$ & $\begin{array}{c}\text { Calcareous } \\
\text { substrate } \\
\text { (ha) }\end{array}$ & $\begin{array}{c}\text { Siliceous } \\
\text { substrate } \\
\text { (ha) }\end{array}$ & P \\
\hline Type 1 & 0 & 351 & $* *$ \\
Type 2 & 40 & 356 & $\mathrm{~ns}$ \\
Type 3 & 48 & 1139 & $* *$ \\
Type 4 & 22 & 944 & $* *$ \\
Type 5 & 175 & 31 & $* *$ \\
Type 6 & 11 & 204 & $\mathrm{~ns}$ \\
Total & 296 & 3025 & - \\
\hline
\end{tabular}


Tab. 5 - Chi square test on two levels of elevation in siliceous and calcareous sites. Chi-square test on weighted values; $(*)$ : $\mathrm{P}<0.05 ;(* *): \mathrm{P}<0.01 ;$ (ns): not significant at $\mathrm{P}<0.05$.

\begin{tabular}{ccrrr}
\hline Substrate & $\begin{array}{c}\text { Pastoral } \\
\text { type }\end{array}$ & $\begin{array}{c}\text { Below } \\
\mathbf{2 2 0 0} \text { m } \\
\text { (ha) }\end{array}$ & $\begin{array}{c}\text { Above } \\
\mathbf{2 2 0 0 ~ m} \\
\text { (ha) }\end{array}$ & P \\
\hline Calcareous Type 2 & 4 & 36 & $\mathrm{~ns}$ \\
& Type 5 & 20 & 155 & $\mathrm{~ns}$ \\
& Type 6 & 3 & 8 & $\mathrm{~ns}$ \\
\hline Siliceous & Type 1 & 107 & 244 & $* *$ \\
& Type 2 & 313 & 43 & $\mathrm{~ns}$ \\
& Type 3 & 772 & 367 & $\mathrm{~ns}$ \\
& Type 4 & 841 & 104 & $* *$ \\
& Type 6 & 202 & 3 & $*$ \\
\hline
\end{tabular}

Tab. 6 - Hierarchical fuzzy analysis: overlaps of each pastoral types (in rows) with the other types (in coumns). All values are given in percentage.

\begin{tabular}{|c|c|c|c|c|c|c|}
\hline Pastoral & type & type & type & type & type & type \\
\hline Type & 1 & 2 & 3 & 4 & 5 & 6 \\
\hline $\begin{array}{l}\text { type } 1 \\
\text { overlaps }\end{array}$ & 65 & 9 & 22 & 3 & 1 & 0 \\
\hline $\begin{array}{l}\text { type } 2 \\
\text { overlaps }\end{array}$ & 1 & 59 & 20 & 3 & 6 & 11 \\
\hline $\begin{array}{l}\text { type } 3 \\
\text { overlaps }\end{array}$ & 9 & 30 & 54 & 5 & 1 & 1 \\
\hline $\begin{array}{l}\text { type } 4 \\
\text { overlaps }\end{array}$ & 1 & 10 & 20 & 67 & 1 & 1 \\
\hline $\begin{array}{l}\text { type } 5 \\
\text { overlaps }\end{array}$ & 0 & 16 & 5 & 1 & 72 & 6 \\
\hline $\begin{array}{l}\text { type } 6 \\
\text { overlaps }\end{array}$ & 0 & 16 & 4 & 1 & 4 & 75 \\
\hline
\end{tabular}

\section{Identification and definition of path- ways between pastoral types}

Fuzzy analysis confirmed the general classification obtained by hierarchical cluster analysis (Tab. 6): correct membership coefficients were between $54 \%$ and $75 \%$. Pastoral types $1,4,5$ and 6 resulted the best defined (correct membership over 65\%), pastoral

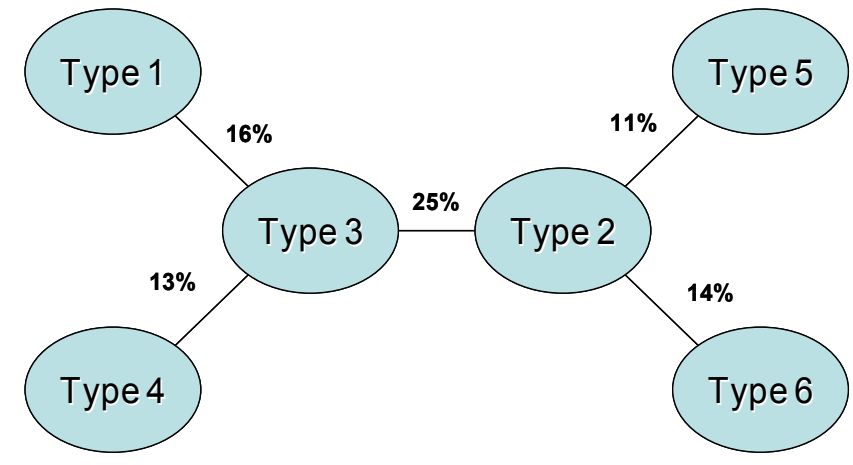

Fig. 3 - Hierarchical fuzzy analysis. The percentage values point out the main overlaps between pastoral types (mean values). types 2 and 3 were more "fuzzy" (correct membership under $60 \%$ ). Very low overlaps were found between types from different ecological sites (overlaps under 3\% between types 1, 4 and 5): larger overlaps were found between types in the same ecological site, but low values resulted between types 5 and 6 (mean overlap 5\%), between types 1 and 2 (mean overlap 5\%) and between types 4 and 6 (mean overlap 1\%). Main overlaps occurred among pastoral types 2 and types 3, 5, and 6 (mean overlaps over 11\%) and between type 3 and types 1, 2 and 4 (mean overlaps over $13 \%$ ). Finally, mean overlap of $25 \%$ resulted between types 2 and 3 (Fig. 3 ). Fuzzy analysis localized pastoral types 2 and 3 at the centre of the vegetation pathways: in particular type 2 was considered the pivot between types 5 and 6 in calcareous sites; type 3 the pivot between types 1 and 2 in siliceous sites above timberline and both types resulted the pivot between types 4 and 6 in siliceous sites below timberline.

Non-parametric test for mean separation on slope, distance from farm, $\mathrm{N}$ and $\mathrm{F}$ indices were then employed for the analysis of pathways among the pastoral types in each ecological site (Tab. 7). In calcareous sites $\mathrm{N}$ index was able to discriminate type 6 (higher nutritive elements concentration) from types 5 and 2 (lower nutritive elements concentration), type 5 was linked to low-moisture environments, distance from the farm pointed out a gradient going from type 5 (average distance $859 \mathrm{~m}$ ) to type 6 (average distance

Tab. 7 - Kolmogorov-Smirnov test on slope, distance from farm, $\mathrm{N}$ and $\mathrm{F}$ ecological indices (values with the same letter in a column are not significantly different at $\mathrm{P}<0.05$ ).

\begin{tabular}{lccccc}
\hline \multicolumn{1}{c}{ Substrate } & Type & slope $(\mathbf{\%})$ & $\begin{array}{c}\text { distance from } \\
\text { farm }(\mathbf{m})\end{array}$ & N index & F index \\
\hline calcareous & Type 2 & $33^{\mathrm{a}}$ & $652^{\mathrm{b}}$ & $2.32^{\mathrm{b}}$ & $2.71^{\mathrm{a}}$ \\
& Type 5 & $21^{\mathrm{a}}$ & $859^{\mathrm{a}}$ & $2.49^{\mathrm{b}}$ & $2.41^{\mathrm{b}}$ \\
& Type 6 & $34^{\mathrm{a}}$ & $412^{\mathrm{b}}$ & $3.03^{\mathrm{AM}}$ & $2.85^{\mathrm{a}}$ \\
\hline siliceous, & Type 1 & $33^{\mathrm{a}}$ & $1198^{\mathrm{a}}$ & $2.24^{\mathrm{b}}$ & $2.64^{\mathrm{ab}}$ \\
above timberline & Type 2 & $25^{\mathrm{a}}$ & $1256^{\mathrm{a}}$ & $2.89^{\mathrm{a}}$ & $2.71^{\mathrm{ab}}$ \\
& Type 3 & $22^{\mathrm{a}}$ & $1228^{\mathrm{a}}$ & $2.42^{\mathrm{ab}}$ & $2.87^{\mathrm{a}}$ \\
\hline siliceous, & Type 2 & $18^{\mathrm{b}}$ & $641^{\mathrm{ab}}$ & $2.67^{\mathrm{b}}$ & $2.85^{\mathrm{ab}}$ \\
below timberline & Type 3 & $24^{\mathrm{ab}}$ & $884^{\mathrm{a}}$ & $2.39^{\mathrm{bc}}$ & $2.90^{\mathrm{ab}}$ \\
& Type 4 & $30^{\mathrm{a}}$ & $793^{\mathrm{ab}}$ & $2.07^{\mathrm{c}}$ & $2.74^{\mathrm{b}}$ \\
& Type 6 & $22^{\mathrm{b}}$ & $555^{\mathrm{b}}$ & $3.19^{\mathrm{AM}}$ & $2.94^{\mathrm{a}}$ \\
\hline
\end{tabular}

$412 \mathrm{~m}$ ), type 2 (average distance $652 \mathrm{~m}$ ) was localized between these two extremes. Slope differences were not significant.

In siliceous sites above the timberline only $\mathrm{N}$ and $\mathrm{F}$ indices were significant and they were able to discriminate type 1 (lower nutritive elements concentration and lower moisture), from type 3 (higher $F$ values) and type 2 (higher $\mathrm{N}$ values). As expected, pastoral types above $2200 \mathrm{~m}$ were the most distant from the farms which were localized at lower altitudes (mean distances between 1198 and $1256 \mathrm{~m}$ ). In siliceous sites below the timberline, shrub-encroached grasslands (pastoral type 4) prevailed on steeply-sloping areas (mean slope 30\%), whereas types 2 and 6 were common on more level areas (mean slope $18 \%$ and $22 \%$ ); type 3 was localized far from the farms (mean distance $884 \mathrm{~m}$ ), whereas type 6 was linked with farm neighbourhoods (mean distance $555 \mathrm{~m}$ ). N index was able to discriminate a gradient from type 6 (highest concentration of nutritive elements) to type 4 (lowest concentration of nutritive elements). Type 4 was also characterized by the lowest $\mathrm{F}$ index values.

\section{Discussion}

Pastoral types were characterized by distinct ecological exigencies, dominant species in each pastoral type were indicators of specific environmental conditions and pastoral characteristics: Carex curvula (dominant species in type 1) is typical on high-altitude and siliceous pastures; N. stricta (type 3 ) is a non-palatable graminoid typical on siliceous grasslands and it is considered an indicator of low stocking rates; $F$. gr. rubra (type 2 ) is a palatable graminoid with broad ecological spectrum; Vaccinium myrtillus and Calluna vulgaris (dominant species in type 4) are dwarf-shrubs which usually encroach mountain grasslands; Sesleria varia and Carex sempervirens (dominant species in type 5) are typical calcareous substrate species and Deschampsia caespitosa (type 6) is a nitrogen and soil moisture richness indicator. Species composition allowed a substantially clear interpretation of productive characteristics and ecological exigencies of the pastoral types: type 1 (Carex curvula type) corresponded to high-altitude pastures; type 2 
Fig. 4 - Proposed State-and-Transition-Models for the studied grasslands. A: calcareous sites, B: siliceous sites above timberland, $\mathrm{C}$ : siliceous sites below timberland. Main sources of data used to support the framework elements are referenced in the figure, effects of pastoral practices on pastoral type dynamics are simplified as follows. A1: grazing in drought periods, erosion (reversion of transition is due to slow natural succession); A2: farm slurry; A3: absence of farm slurry and grazing. B1: grazing abandonment; B2: increase of grazing; B3: increase of grazing; B4: reduction of grazing. $\mathrm{C} 1$ : grazing reduction under minimal stocking rate (reversion of transition requires shrub elimination, seeding and grazing management); $\mathrm{C} 2$ : increase of grazing from minimal stocking rate to potential stocking rate; $\mathrm{C} 3$ : reduction of grazing from potential stocking rate; C4: farm slurry and localized overgrazing; C5: absence of farm slurry, balanced stocking rate.

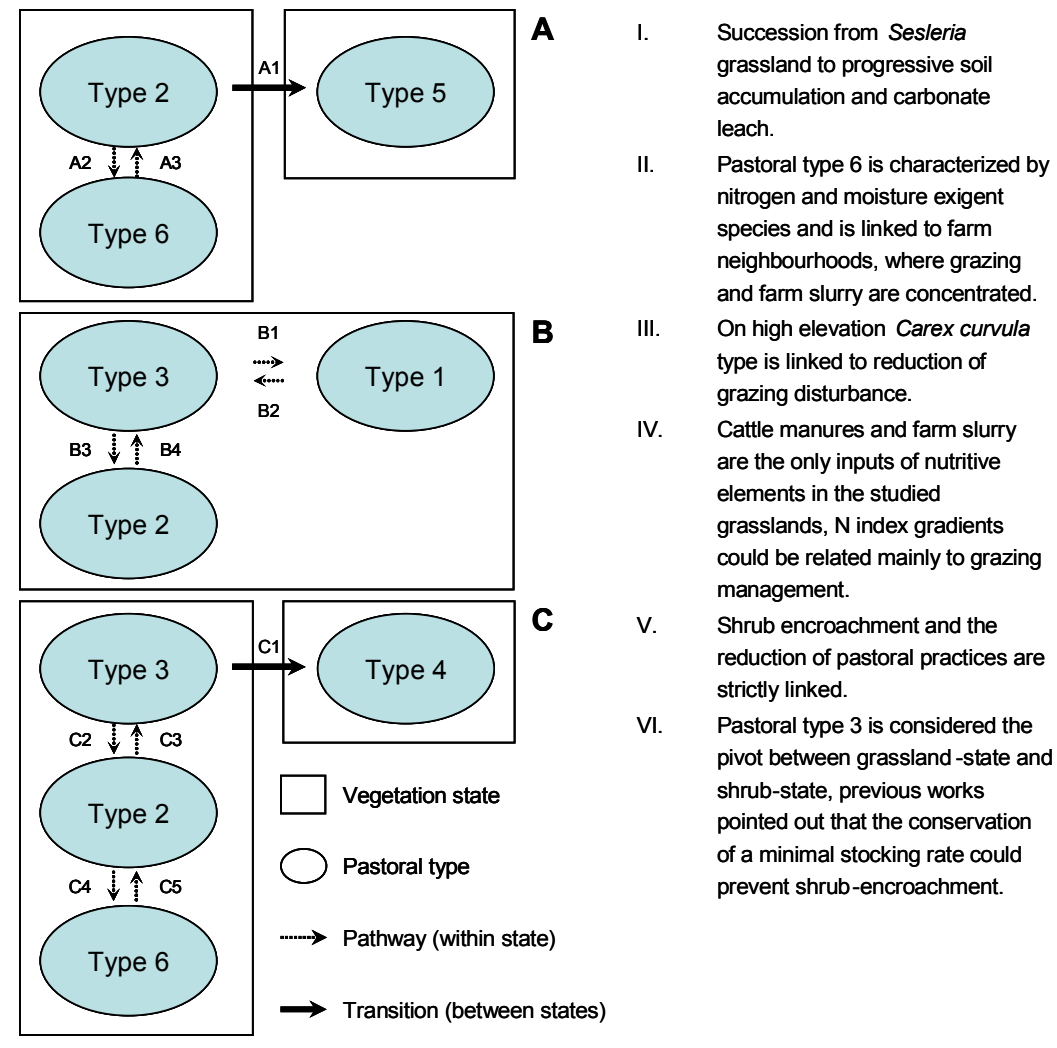

grassland towards woodland and it was linked with siliceous sites below the timberline, S. varia type was linked with calcareous sites, type 6 was related with high fertility conditions which are typical in the farm neighbourhood.

$\mathrm{N}$ index was able to describe adequately the differences between the pastoral types and the pathways defined by hierarchical fuzzy analysis: a fertility gradient was highlighted in site A going from type 2 to type 1 and in site B going from type 6 to type 4 . F index was able to discriminate type 5 (lower moisture) and type 6 (higher moisture). This evidence was probably in relation with the high permeability of the calcareous areas (type 5) and the specific low permeability of the siliceous areas (dominated by the Val Visdende Formation) which was worsened by the presence of localized overgrazing in type 6.

Slope differences highlighted a considerable relationship between the shrub-encroached type and sloping sites. According with other works on alpine territories (e.g., Tasser et al. 2007), this evidence could be explained by a reduction in pastoral practices: in the area studied cattle routes and grazing depended strongly on topography, thus sloping sites were the primary areas affected by a reduction in pastoral practices and this could be confirmed by the low $\mathrm{N}$ index values found in type 4 .

Deschampsia caespitosa type was found to be the pastoral type related with the neighbourhood around the farms and this evidence was probably linked with the organic manure practices which were traditionally concentrated in the grasslands around the farm because these pastures were characterized by the highest productive potential and by higher facilities for mechanization. The high nutrient availability in pastoral type 6 was confirmed by the high $\mathrm{N}$ index values, the high $F$ index values could be related with the presence of localized overgrazing

The organization of data and results allowed the assessment of one STM for each ecological site (Fig. 4): particular attention was dedicated to the definition of relationships between $\mathrm{N}$ index results and pastoral types and its management implications.

In calcareous sites the pathway between pastoral types 2 and 5 was not related to $\mathrm{N}$ index differences, it is probably linked with natural evolution of vegetation on deeper soils and progressive carbonate leach, whereas reversion of the transition (from type 5 to type 2) is related with erosion and soil losses (Gusmeroli et al. 2004). Grazing in drought periods is a very likely driving factor behind erosion and regression to type 5 , but further studies are needed to support this evidence.

STM on siliceous sites above timberline was classified as a one-state-model because no transitions were identified. Grazing disturbance favours grazing-adapted species and the shift from type 1 to type 2 through type 3 , but there was no evidence of hard-torevert transitions between types. As a result, higher stocking rates were linked with type 
2 , reduction of grazing practices were linked with pastoral types 3 and 1 .

Two states were defined in site C: types 2, 3 and 6 were part of the "open grassland" state and type 4 was part of the shrub-encroached state. The transition to type 4 was linked with progressive reduction of grazing and related practices, whereas intensive practices such as roller-chopping, or fire and reseeding are needed to revert the transition. Type 6 was linked with farm manure practices and localized overgrazing; type 2 was linked with grazing and the absence of manure; the shift to types 3 was linked with a progressive reduction in grazing. Even if no differences in shrub species presence were highlighted between types 2 and 3 (chamaephytes SC was $6 \%$ and $5 \%$ respectively), fuzzy analysis clearly pointed out a higher overlap of type 3 with type 4 . As a result type 3 was identified as the critical pastoral type where stocking rate should be maintained above a critical value, in order to avoid the transition of grasslands to the shrub-encroached state. In previous works on this areas this critical stocking rate was called "minimal stocking rate" which was assessed as the $25 \%$ of the carrying capacity (Argenti et al. 2000).

\section{Conclusions}

The employment of pastoral types as vegetation units in a state-and-transition framework was successful. This study allowed us to build one STM framework for each ecological site, we combined statistical evidence (obtained by cluster analysis, fuzzy analysis and non-parametric tests) and available information to propose a general framework describing grasslands in the area under study, based on field data and empirical evidence. The STM approach led to a valid framework which could be useful in the description of alpine grasslands, in particular the classification of transitions between different states could be of great help in the identification of at-risk grassland communities and in the application of sustainable conservation practices.

In siliceous sites below the timberline, pastoral abandonment was recognized as causing the state transition from an open grasslands state to a shrub-encroached state. We identified pastoral type 3 as the critical pivot in the STM. Maintaining a minimal stocking rate in these grasslands could be appropriate to avoid the state transition, though further studies are needed to fully understand the relationship between grazing management and the conservation of productive potential of mountain grasslands.

Grazing management is among the main factors determining vegetation changes in grasslands, $\mathrm{N}$ index analysis allowed us to throw light on the relationship between the effects of grazing on nutrient availability in soil and vegetation shifts. However, the development of techniques for ecosystem monitoring requires a deeper knowledge about communities' resilience, feedback mechanisms and description of transitions and restoration pathways (Groffman et al. 2006), including the assessment of valid threshold indicators that would require several years and specific research projects (Pyke et al. 2002).

Shrub encroachment is probably the most evident change in alpine pastures and our goal was to point out that shrublands represent alternative hard-to-revert states. Beyond a certain point (ecological threshold) grazing management is no more effective to revert the transition from grassland to shrubland and intensive measures are required (Bestelmeyer et al. 2009. We believe that grassland conservation policies should concentrate on prevention and grazing management through monitoring programs rather than restoration. It is possible that many areas will be appropriately left to natural succession, as pasture restoration by mechanical operations or burning could be ineffective or unsustainable (Pihlgren \& Lennartsson 2008). In this case grazing limitation is of primary importance to reduce erosion risks and the perspective of a radical change in traditional land management should be carefully considered.

\section{Acknowledgements}

The authors contributed in equal part to the work. The work was carried out as part of the the Italian FISR "Pro-Alpe" project, coordinator Dr. E. Piano (publication no. 33).

\section{References}

Argenti G, Sabatini S, Staglianò N, Talamucci P (2000). Effect of different stocking rates on Nardus stricta pastures in some alpine and Apennine environments of Italy. In: "Quality and promotion of animal products in mountain areas" (Peeters A, Frame J eds). Proceedings of the FAO/CIHEAM Mountain Pastures Network, Luz-Saint-Sauveur, France, pp. 66-69.

Barthram GT, Marriott CA, Common TG, Bolton GR (2002). The long-term effects on upland sheep production in the UK of a change to extensive management. Grass and Forage Science 57: 124- 136. - doi: 10.1046/j.13652494.2002.00309.x

Bassignana M, Bornard A (2004). Vegetation typology as a management tool for intra-alpine summer pastures. In: Proceedings of the " $20^{\text {th }}$ General meeting of the European Grassland federation" (Lúscher A, Jeangros B, Kessler W, Huguenin O, Lobsiger M, Millar N, Suter D eds). Luzern, Switzerland, pp. 769-771.

Beisner BE, Haydon DT, Cuddington K (2003). Alternative stable states in ecology. Frontiers in Ecology and the Environment 1: 376-382. - doi: $10.1890 / 1540-$

9295(2003)001[0376:ASSIE]2.0.CO;2

Bestelmeyer BT, Brown J R, Havstad KM, Alex- ander R, Chavez G, Herrick JE (2003). Development and use of state-and-transition models for rangelands. Journal of Range Management 56: 114-126. - doi: 10.2111/08-146

Bestelmeyer BT, Tugel AJ, Peacock GL, Robinett DG, Shaver PL, Brown JR, Herrick JE, Sanchez H, Havstad KM (2009). State-and-transition models for heterogeneous landscapes: a strategy for development and application. Rangeland Ecology \& Management 62-: 1-15. - doi: 10.2111/08-146

Bornard A, Dubost M (1992). Diagnostic agroécologique de la végétation des alpages laitiers des Alpes du Nord humides: établissement et utilisation d'une typologie simplifiée. Agronomie 12: 581-599. - doi: 10.1051/agro:19920802

Braga GP, Carloni GC, Colantoni P, Corsi M, Cremonini G, Frascari F, Locatelli D, Monesi A, Pisa G, Saasi FP, Selli R, Vai GB, Zirpoli G (1971). Note illustrative della carta geologica d'Italia. Foglio 4c-13 Monte Cavallino-Ampezzo, Italian Geological Service, Roma, Italy. Briske DD, Fuhlendorf SD, Smeins FE (2005). State-and-Transition models, thresholds and rangeland health: a sinthesis of ecological concepts and perspectives. Rangeland Ecology \& Management 58: 1-10. - doi: 10.2111/15515028(2005)58 < 1:SMTARH $>2.0$. CO;2

Cavallero A, Aceto P, Cugno D, Gorlier A, Lombardi G, Lonati M, Martinasso B and Tagliatori C (2005). Pasture vegetation types of W-Alps (Piedmont, Italy): a handbook for their identification and management. In: Proceedings of the $13^{\text {th }}$ Meeting of the FAO-CIHEAM Mountain Pastures Network "Quality production and quality of the environment in the mountain pastures of an enlarged Europe" (Biala K, Nösberger J, Parente G, Peeters A eds). Udine, Italy, pp. 91-96.

Daget P, Poissonet J (1969). Analyse phytologique des prairies. Applications agronomiques, CNRS CEPE, Montpellier, France.

Ellenberg H (1988). Vegetation ecology of central Europe. Cambridge University Press, Cambridge, UK.

Ferrari C, D’Antuono LF (1981). Misura del legame tra tipi di vegetazione e fattori ambientali mediante sovrapposizione cartografica In: "La cartografia della vegetazione per la gestione del territorio", C.N.R. AC/1/129: 131-144.

Groffman PM, Baron JS, Blett T, Gold AJ, Goodman I, Gunderson LH, Levinson B, Palmer MA, Paerl HW, Peterson GD, Poff NL, Rejeski OW, Reynolds QJF, Turner MG, Weathers KC, J Wiens (2006). Ecological thresholds: the key to successful environmental management or an important concept with no practical application? Ecosystems 9: 1-13. - doi: 10.1007/s10021-0030142-z

Gusmeroli F, Della Marianna G, Arosio G, Pozzoli L (2004). La vegetazione dei pascoli dell'Alta Valtellina. Comunità montana Alta Valtellina, Fondazione Fojanini di Studi Superiori, Italy.

Jackson RD, Bartolome JW (2002). A state-transition approach to understanding nonequilibrium plant community dynamics in California grass- 
lands. Plant Ecology 162: 49-65. - doi: 10.1023/A: 1020363603900

Jewell PL, Güsewell S, Berry NR, Käuferle D, Kreuzer M and Edwards PJ (2005). Vegetation patterns maintained by cattle grazing on a degraded mountain pasture. Botanica Helvetica 115 (2): 109-124. - doi: 10.1007/s00035-005-0727-6

Kaufman L, Rousseeuw PJ (1990). Finding groups in data: an introduction to cluster analysis, Wiley \& sons, New York, USA.

Kent M, Coker P (1992). Vegetation description and analysis. A practical approach. Belhaven Press, London, UK.

Landolt E (1977). Ökologische Zeigerwerte zur Schweizer Flora. Veröffentlichungen Geobotanisch Institut Rubel, pp. 64.

Lonati M (2005). Analisi di gradienti ecologici in formazioni pascolive mediante gli indici di Landolt: un esempio in Valle Maira. Italia Forestale e Montana 5: 629-640.

MacDonald D, Crabtree JR, Wiesinger G, Dax T, Stamou N, Fleury P, Gutierrez Lazpita J, Gibon A (2000). Agricultural abandonment in mountain areas of Europe: environmental consequences and policy response. Journal of Environmental Management 59 (1): 47-69. - doi: 10.1006/jema.1999.0335

Muradian R (2001). Ecological thresholds: a survey. Ecological Economics 38 (1): 7-24. - doi: 10.1016/S0921-8009(01)00146-X

Nösberger J, Rodriguez M (1996). Increasing biodiversity through management. In: Proceedings of the $16^{\text {th }}$ General Meeting of the European Grassland Federation "Grassland and Land use systems" (Parente G, Frame J, Orsi S eds). Grado (GO), Italy, pp. 949-956.
Pignatti S (1982). Flora d'Italia. Edagricole, Bologna, Italia, $3 \mathrm{VV}$.

Pihlgren A, Lennartsson T (2008). Shrub effects on herbs and grasses in semi-natural grasslands: positive, negative or neutral relationships? Grass and Forage Science 63: 9-21. - doi: 10.1111/j.1365-2494.2007.00610.x

Pollock ML, Legg CJ, Holland JP, Theobald CM (2007). Assessment of expert opinion: seasonal sheep preference and plant response to grazing. Rangeland Ecology and Management 60 (2): 125-135. - doi: 10.2111/06-032R2.1

Pyke OA, Herrick JE, Shaver P, Pellant M (2002). Rangeland health attributes and indicators for qualitative assessment. Journal of Range Management 55: 584-597. - doi: 10.2307/4004002

Quétier F, Thebault A, Lavorel S (2007). Plant traits in a state and transition framework as markers of ecosystem response to land-use change. Ecological Monographs 77: 33-52. - doi: 10.1890/06-0054

R Development Core Team (2006). R: a language and environment for statistical computing. $\mathrm{R}$ Foundation for Statistical Computing, Vienna, Austria.

Raunkiaer CC (1934). The life forms of plants and statistical plant geography. Oxford University Press, Oxford, UK.

Romero-Calcerrada R, Perry GLW (2004). The role of land abandonment in landscape dynamics in the SPA Encinares del río Alberche y Cofio, Central Spain, 1984-1999. Landscape and Urban Planning 66: 217-232. - doi: 10.1016/S01692046(03)00112-9

Sabatini S, Argenti G, Staglianò L, Bottai L (2001). Applicazione di tecniche di spazializza- zione per la determinazione speditiva del valore pastorale in un comprensorio pascolivo. In: Proceedings of $31^{\text {st }}$ Symposium of Italian Agronomy Society. "Strategie agronomiche al servizio della moderna agricoltura" (Mariotti M, Pampana S eds). Pisa, Italy, pp. 25-26.

Sabatini S, Albertosi A, Argenti G, Bianchetto E, Staglianò N (2003). Improvement of pastures encroached by shrubs through animal grazing in an Italian alpine environment. In: Proceedings of the $12^{\text {th }}$ Symposium of the European Grassland Federation, "Optimal forage systems for animal production and the environment" (Kirilov A, Todorov N, Katerov I eds). Pleven, Bulgaria, pp. 74-76.

Stringham TK, Krueger WC, Shaver PL (2003). State and transition modelling: an ecological process approach. Journal of Range Management 56: 106-113. - doi: 10.2307/4003893

Tasser E, Walde J, Tappeiner U, Teutschc A, Noggler W (2007). Land-use changes and natural reforestation in the Eastern Central Alps. Agriculture, Ecosystems \& Environment 118: 115-129. doi: 10.1016/j.agee.2006.05.004

Wallis De Vries MF, Parkinson AE, Dulphy JP, Sayer M, Diana E (2007). Effects of livestock breed and grazing intensity on biodiversity and production in grazing systems. 4. Effects on animal diversity. Grass and Forage Science 62: 185-197. - doi: 10.1111/j.13652494.2007.00568.x

Westoby M, Walker BH, Noy-Meir I (1989). Opportunistic management for rangelands not at equilibrium. Journal of Range Management 42: 266-274. - doi: 10.2307/3899492 